\title{
肥満における脂質代謝の特性
}

\author{
馬場茂明 \\ 神戸大学医学部内科学 (神戸市生田区楠町 7 丁目)
}

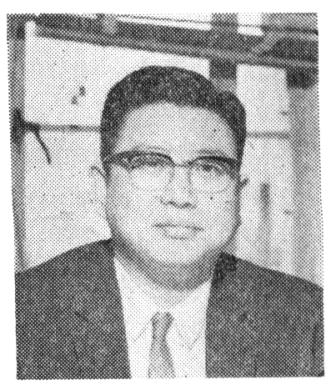

\section{Features of Fat Metabolism on Obesity}

\author{
Shigeaki BABA
}

The 2nd Dept. Internal Medicine Kobe University School of Medicine

(12 Kusunoki-cho 7-Chome, Ikuta-ku, Kobe)

\section{1 いとぐち}

肥満した人の特徴は動作が緩慢で, 一日の食事回数, 食事量も意外に少なく，また，一旦肥満するとなかなか やせないことがよく知られている。換言すれば，正常人 と同じ基礎代謝率をもった肥満者では少量の食事摂取で 体重の維持が可能であり, 運動の減少はかえってそれら を助長するといえる。寒冷に対しても肥満したものは抵 抗が強く, 皮下脂肪の貯積は寒さに対する絶縁作用をも っておるほか，寒冷暴露による代謝率の上昇も最も少な いとされている。

Lennon ら (1967 $)^{1)}$ は寒冷暴露汇対する血中遊離脂 肪酸 (FFA) の上昇は肥満者において少ないこと, Wydkam ら $(1968)^{2)}$ は正常人を $-6.6^{\circ} \mathrm{C}$ 以下に暴露させ ると明らかに代謝率の上昇を久るが肥満者は $-12.2^{\circ} \mathrm{C}$ 以下にしないと，その上昇を認めないと報告している。 しかし, 一方, ふとりはじめの人達は多食であることも よく知られている。このように肥満者汇正常人と違っ たさまざまな代謝上の特性があるが, 本稿では臨床化学 的立場より概説をこころみる。

\section{2 肥満者の特性に関連する条件}

肥满者をやせさせることはきわめてむずかしいことを 述べたが, その理由として, 肥満者の脂肪細胞には基本 的に, 遺伝的代謝欠損があり，とくに酵素レベルでの不 全が，この代謝過程に存在するためではないかと考えら れている。

Galton (1966 ${ }^{3)}$ は肥満患者の脂肪細胞は alpha-glycero-phosphate dehydrogenase 活性が低下しているこ とより glycero-phosphate の酸化が減弱していると報告 し, glycerol-phosphate は脂肪の合成, 貯蔵に使われる ため, 脂肪の沈着は起こりやすいとした。

また Galton と Bray $(1967)^{4)}$ は，原因の明らかな中
枢障害を伴った肥満者にあっては, その脂肪細胞に上記 のような特定の酵素欠損を証明する成績淂られなかっ たことより,やはり単純性肥満には遺伝的先天性の酵素 欠損があるのではないかと Galton の成績を支持する報 告をしている。たしかにわれわれの臨床経験からしても 肥满汇遺伝的背景が濃厚にみうけられる。

しかし, 肥満の発生は体脂肪の沈着を主体とするが, 特定酵素の欠損の結果のみで異常肥満が形成されるとは いいがたく, 本質的には過食, すなわち, エネルギー摂 取の過剩を前提としなければならない。いずれにしても 肥満と食㤵とはきわめて密接な関係にあることはいうま でもない。たとえば, 精神的に, 亦るいは病的に食欲の 異常克進をきたすことがある。とくに食欲中枢（飽食中 枢) の障害された間脳疾患者では, 異常な食欲克進を示 乙, 肥満, 高血糖の持続が常にみられる。

また，同じカロリー食であっても，食事回数を一日五 回亦るいはそれ以上に分けてとる場合と，一日三回以下 の場合とでは, 体重の変化は前者の方にむしろ減少する 傾向があり, 同カロリーであっても食事回数の少ない者 程ふとる傾向がある。このように肥満の代謝機構はきわ めて複雑な多数の因子によって維持されているといえる が, 脂肪の生成, 分解過程を中心にその代謝特性をさぐ ってみよう。

\section{3 脂質代謝の調節機構}

そこで“肥満とは何か”という first step にたちかえ ると, 体脂肪の異常に蓄積した状態を肥満というべきで あり, 脂肪の合成, 蓄積は主として脂肪細胞で行なわれ る。

したがって肥満の代謝特性は主として脂肪組織党中心 に, 血流を介して, 肝, 心筋, 末梢筋組織㧍よで腸管上 りの吸収などによって影響される。生体にとって脂肪組 織は一種の防御作用にすぎないとされた時代から, 現在 
ではむしろ動的な代謝調節機関と解釈されている。そこ で肥満の代謝を論議する前に生体における脂質代謝機構 について概説する。

\section{$3 \cdot 1$ 脂質の生体内調節機構}

脂肪細胞における中性脂肪の合成には二つの合成過程 が考えられる。すなわち，ブドウ糖よりの合成系と血中 中性脂肪（トリグリセリド，以下 TG と略す）が脂肪 組織に直接取りこまれる過程である。すなわち，生体の 脂質調節機構はエネルギー代謝と関連して相互の転送機 転が成立しており，図-1 はそれを模式化したものであ る。この関係をさらに詳しく説明すると，摂取された脂 肪は図-2 のように，腸管内にてリパーゼと胆汁によっ て分解され，脂肪酸， $\beta$-モノグリセリドとなり，腸上皮 細胞に取りこまれ，再び ATP，Co.A.の作用で TG に再合成され，細胞内のタンパク質と結合し，乳ビ球と なってリンパ管にはいる。一方短鎖脂肪酸は直接門脈系 にはいり，肝にはこばれる。

血中乳ビ球の $45 \%$ 以上は肝を通過し，ここで加水分 解され, 脂肪酸 (FA と略す) となり, 一部は再エステ ル化された後，リポタンパク質になる。また，外因性乳 ビ球の $25 \%$ は脂肪組織で直接同化される。この同化作

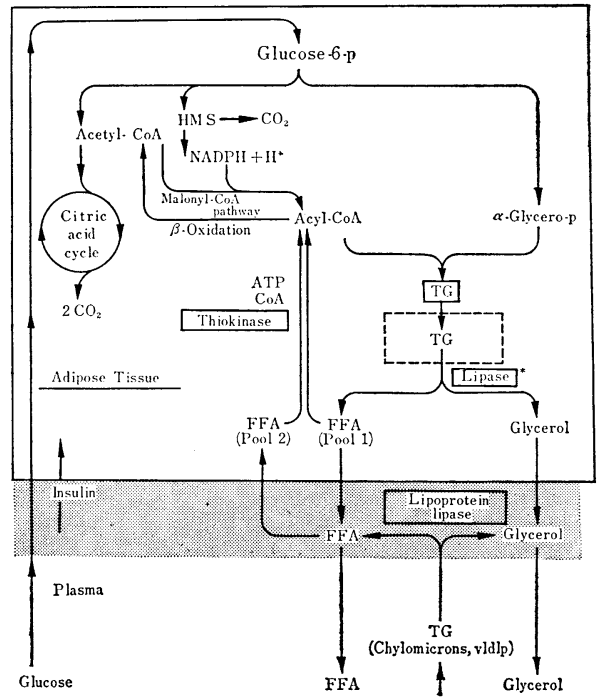

H.A. Harper, Review of Physiological Chemistry, 10; (1965)より

図-1 Adipose Tissue

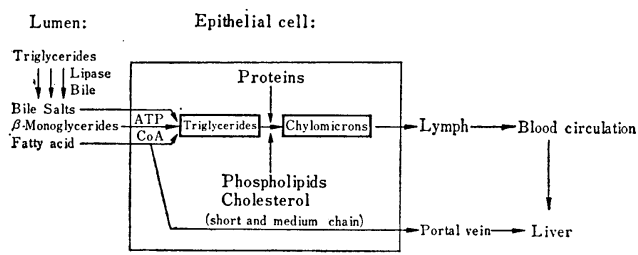

図-2 トリグリセリドの吸収過程
用については不明なところがいくらかあるが，細胞には いるまえに TG が細分化されると考えられている。

すなわち，脂肪細胞の血管壁にあるとされているリポ プロテインリパーゼは $\alpha$-エステル脂肪酸と一次的な親 和性をもち，TG を FA とグリセリンに分解する。こ

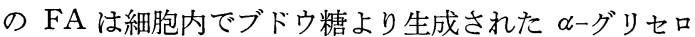
リン酸塩と再エステル化して TG となる（図-1)。

一方，脂肪組織より血中へ放出された非エステル型脂 肪酸は肝にはこばれて，TGに合成されるか，あるいは さらに酸化され水と $\mathrm{CO}_{2}$ になるか，アセトン体生成素 材となる。

また，コレステリンとともにエステル化するか，リポ タンパク質の構造分子としてリン脂質となり, 種々の膜 成分ともなる。

これらの脂肪の代謝調節は生体内エネルギーの消費, 需要に基づいて合目的に調節されているし，また，それ らは各種の神経性, あるいはホルモン性因子によっても 左右されていると考えてよい。

脂肪細胞中の中性脂肪は, 細胞内のリポプロテインリ パーゼによって分解され，グリセリンと脂肪酸となり， 細胞外へ放出されるが，このリポプロテインリパーゼは ホルモン感受性がつよく，とくにカテコールアミン，グ ルカゴン, ACTH, GH などの作用を強く受ける。その 作用は adenyl cyclase 活性を高め, ついで ATP より cyclic $3^{\prime}, 5^{\prime}$-AMP の生成を高める。この cyclic AMP はプロテインキナーゼに働き，不活性リパーゼを活性化 すると考えられている。とくにカテコールアミンが最も 強力に作用することが証明されている（図-3）。

最近藤井は cyclic AMP の lipolytic action につい て, 従来の見解と異なる知見を報告している。すなわ

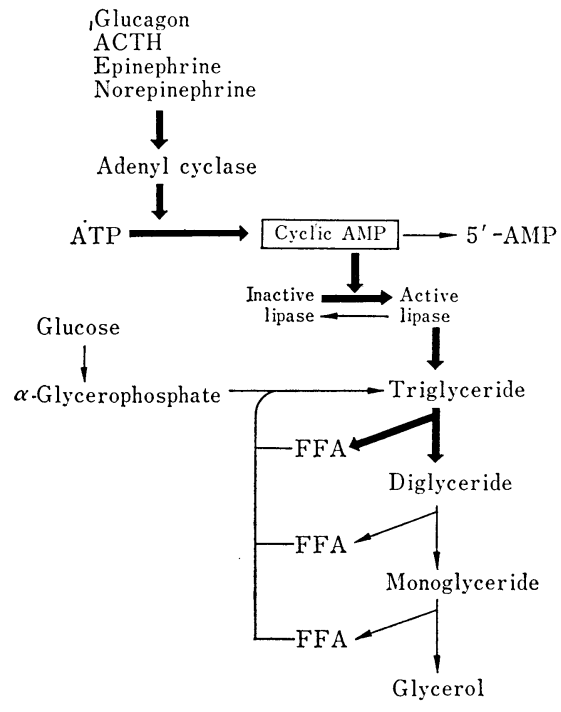

図-3 
ち, 脂肪細胞内のリパーゼ活性度を検討した結果，アド レナリンによりリポタンパクリパーゼが活性化されるこ とは証明されたが，リパーゼに直接働くのではなく，脂 肪のリン脂質に働いて, リパーゼの作用を受けやすくす るのであると報告している。

このようなことより，脂肪細胞はストレス，感情の興 奮, 起立挙立, 絶食など環境因子に対しても容易に影響 され, その結果みられる脂酸動員は主として自律神経 系，とくに交感神経系の影響がまず第一義的であると考 えられている。

しかし, 肥満にみられる血中高脂酸血は特異的であ りある程度へキサメトニウムやニコチン酸にて抑制さ れるが, 完全でないことより肥満には自律神経の関与以

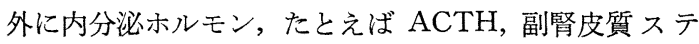
ロイド，成長ホルモンなどの影響があると考えられてい る。

\section{$3 \cdot 2$ 脂肪の合成過程}

脂肪酸合成能はアセチル $\mathrm{CoA}$ カルボキシラーゼによ って第 1 ステップが触媒されるので，その反応速度によ って合成能の程度を知ることができるが，この過程には 二つの重要な過程が糖代謝と関連している。

すなわち，アセチル CoA がミトコンドリア内で pyruvate dehydrogenase によって焦性ブドウ酸より作ら れること，および好気性解糖系 (pentose cycle) におけ る還元ヌクレオチド (NADPH) の形成とが脂肪酸合成 に関与する重要な条件である。

以上の意味上り肥満は, 糖代謝と密接に関連するとい える。しかし, 肥満が桾尿病の前階程, もしくは肥満す なわち糖尿病とはいいがたいことも近年の研究より次第 に明らかにされつつある(このことについては紙面のつ ごうで省略する)。

そこで糖代謝との関連における脂肪酸合成について は, acetly-CoA の形成過程にミトコンドリア内外で の転送機転が二通りあると考えられている。ひとつは carnitine ( $\gamma$-trimethyl-ammonium $\beta$-hydroxy butyrate) によってミトコンドリア外へ acetyl-CoA を転送する機 転である。すなわち，ミトコンドリアへ移入したピルビ ン酸は acetyl-CoA を作りっこれは carnitine actyl transferase によって acetyl carnitine となりミトコン ドリア膜を通過し細胞質へ出る。そこで, acetyl-CoA と carnitine が遊離され, ついでこの acetyl-CoA は脂 酸合成の素材となる(図-4)。

もら一つの系路は 図-5 に示すようにピルビン酸より 生成された acetyl-CoA とオキザロ酢酸との縮合によっ て citrate を作り, citrate がミトコンドリア膜を通過 し, citrate cleavage enzymeによって再び acetyl-CoA が生成され，ついでマロニール CoA を経て FA の合 成が行なわれる。したがって，この citrate cleavage

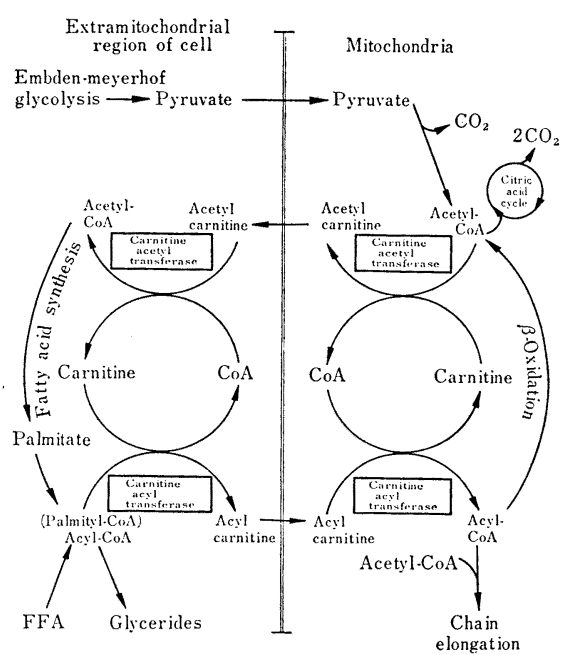

H. A. Harper, Reviews of Physiological Chemistry, 10, (1965) \&り

図-4

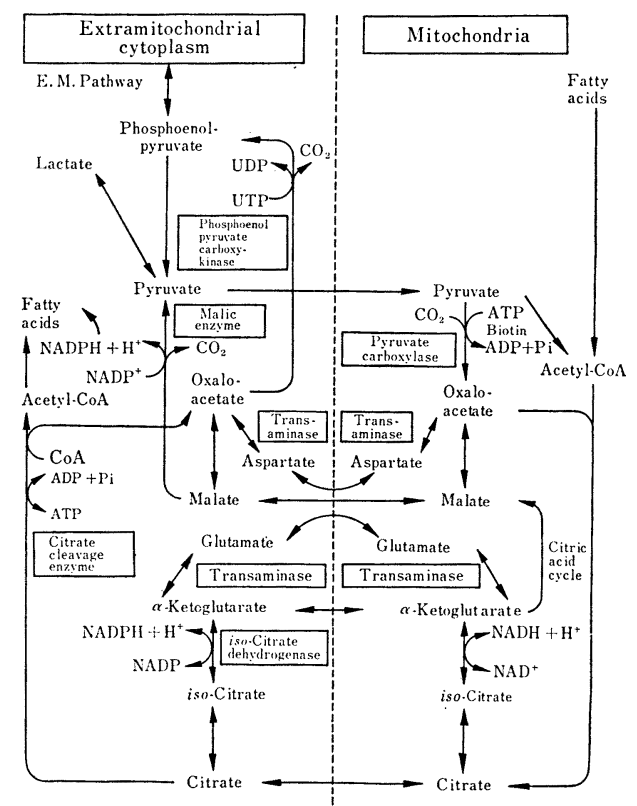

H. A. Harper, Reviews of Physiological Chemistry, 10, (1965より)

図-5

enzyme の活性と先に述べた acetyl-CoA carboxylase 活性度は脂肪酸合成能と比例するといえる。

一方脂肪酸合成のための還元過程における Co-factor として重要な役割を演ずる NADPH の形成は, 好気性 解糖系の pentose-cycle 中で形成される。すなわち一分 子の G-6-P より CoA, pentose と二分子の $\mathrm{NADPH}$ ができる。このほかリンゴ酸より焦性ブドー酸への過程 で malic enzyme による酸化的脱炭酸過程にも NADPH 
が作られる。

これら脂肪酸合成の場は主として脂肪組織あるいは肝 に拉いて行なわれる。ラットを高脂肪食で飼育するか， 飢餓状態, あるいは糖尿病にすると脂肪酸の合成は著し く減少するが，糖質投与によって飽和および単不飽和脂 肪酸の合成が促進され，インスリン注射によってさら に数倍の合成がみられる。この場合, 先述の malic enzyme とか citrate cleavage enzyme, acetyl-CoA carboxylase の活性は著しく上昇することが証明されてい る。したがって糖質およびインスリンは脂肪酸合成に重 要な因子をなすもので, とくに肥満および糖尿病におけ る代謝異常が脂質代謝との関連性において重視されるゅ えんでもある。すなわち，桾質の過剩摂取とともに充分 なインスリンがあれば生体はますます脂肪の沈着, 肥満 がみられることはいうまでもない。糖尿病はインスリン の欠乏によって発症する代謝障害であるため, 肥満する といらよりやせる方向に代謝がむかっていることは理解 できるが，実際は肥満者に糖尿病が多いことはどのよう に説明すればよいのであろらか。

以下肥満の特性をみながらいくらかの説明を試みる。

\section{4 脂満の代謝特性}

肥満の形成，およびその維持に関しては上述の代謝機 構に基づき，エネルギー源としての食物攝取量の増加 と, 脂肪合成過程の促進を要し, また脂肪異化作用の抑 制が働かねばならない。

そこで肥満にみられる一般的特徵を代謝系を中心にひ ろってみると以下のようなものがあげられる。

\section{$4 \cdot 1$ 血中インスリンの上昇}

肥満者には血中インスリンの上昇がみられ，愺ラ氏島 の肥大を認める。このことはヒトのみならず動物実験に おいても証明されているが，この血中高インスリンの発 生に関しては, 食事の過剩摂取と末梢組織の糖利用の阻 害に基づく，インスリン需要の増大によると考えられて いる。

また，ブドウ糖負荷後，しばしば血糖上昇にひきつゔ いて低血糖を起こすが，これも肥満にみられる高インス リン血のためと考えられている。しかし, 肥満者はこの ような高インスリン血にかかわらず，糖尿病に近い代謝 異常が認められ, 先述のよ5にこの両者の代謝位相に矛 盾のあることが指摘される。すなわち肥満者のあるもの には糖の忍容力も低下し，外来性インスリンにも抵抗を 示す。

したがって肥満は糖尿病の前症であるとさえ考えられ ているが，この相反する高インスリン血と高血糖の共存 に対する解説が必要となってくる。

肥満者より分離した脂肪組織をコラゲナーゼで処理し て, 組織より脂肪細胞を遊離させ, 試験管内実験を行な
らと, 添加インスリンに対する作用は明らかに低下を示 した。これは組織重量当たりの糖利用度を規準として表 現した結果であり，フラスコ中の組織内の DNA 量を 基準としてみると，肥満者も非肥満者の脂肪細胞におけ る楉利用も，またインスリン作用も差のないことが証明 された

さらにインスリン負荷試験で，一定量を静注負荷した 場合，たしかに肥満者では血糖の降下率は少なく抵抗す るようにみえるが，インスリン負荷量を体重当たりとし て投与すると非肥満者に対する血糖降下作用と変わりの ないことも判明した。

また， ${ }^{131}$ I-インスリンの分解能を肥満マウスの脂肪組 織で調べると対照マウスよりむしろ増加しているという 報告むなされている ${ }^{6)}$ 。したがって上記の成績を総合す ると, 脂肪組織の代謝は組織片中に含まれる細胞数に大 きく支配されるため, 肥大した細胞を多く含む肥満者の 脂肪組織は重量当たりの代謝活性は低いといらことにな る。感受性は細胞の大きさと逆相関にあるといえる。一 見糖尿病に近い代謝機構があるとみられるのもこのため と考えられる。事実, 臨床的にも, 実験的にも, 食事制 限によって体重減少を計ると, 細胞の縮少がみられ, 糖 利用, 感受性が再び回復する成績によっても喠付けられ よう。

一方, 高インスリン血の発生機序については不明であ るが，糖忍容力の低下したもの程インスリンレベルは高 いこと，成人より小児にこの傾向がつよく認められる。 またグルカゴン投与によるインスリン反応も肥満者に高 く，かつ持続する傾向があるといわれる7)。このような 機作も高インスリン血の背景をなしていると考えられ る。

また，血中にはインスリン以外に，抗インスリン血清 にて抑制されないインスリンょう活性物 質 (nonsuppressible insulin-like activity (NSILA) があり, 肥満では正常対象より常に高值を示し，絶食をすると NSILA は正常者では減少するのに，かえって増加する といわれる ${ }^{8)}$ 。このとは脂肪合成の促進にとってはま すます協調的であるし，また脂肪動員の抑制にもつなが るものであろう。すなわち, 肥満者のやせにくい理由の 一つと考えられる。

さらに肥満者には未知のインスリン拮抗因子の増加が 考えられる。これら諸因子が上述の因子と重なり糖の忍 容力の低下をきたすものと思われるが，もし，肥満者に 糖尿病の遺伝的素因があれば容易に糖尿病の発症がみら れるであろうことは理解できるであろう。

$4 \cdot 2$ ブドウ糖, パルミチン酸エステル, $\beta$-オキシ酪 酸エステルの酸化能の低下と血中脂肪酸の上昇 固定化した肥満者にあってはブドウ糖の酸化が低下し ていることは先にも述べたが，さらに脂酸自体に解糖系 


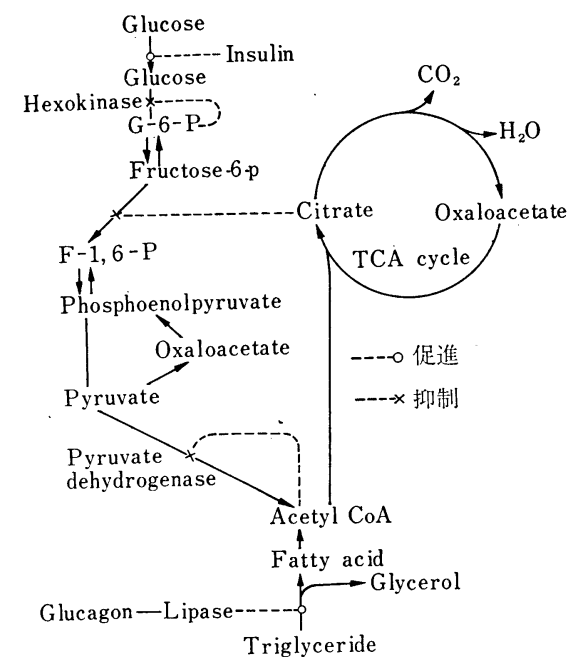

図-6 Glucose-fatty acid cycle (Randle; 1964)

酵素活性に対する抑制が知られている。すなわち，肥満 者血中の脂肪酸上昇は特異的であり, その二次的変化と して解糖系過程の抑制が発現すると考えられる。

Randle ら $(1964)^{11)}$ は, この脂酸増加に伴う機構を glucose-fatty acid cycle (図-6) として, その feedback 機構を説明している。この概念は最初は筋組織における 解糖酵素系で影著に認められると報告したが，その後， 弓狩 $(1967)^{9)}$, Weber らは glucokinase, G-6-P dehydrogenase, pyruvic acid kinase, acetyl-CoA carboxylase への抑制作用は肝細胞を中心に行なわれると報告 し, 組織内で遊離脂肪酸 (FFA) はなんらかの機構でイ ンスリン作用を打ち消そうとしている ${ }^{9), 11) 。 ~}$

以上のような血中脂肪酸の上昇は肥満者にみられる特 徵であるが，肥満の時期によっていくらか異なってい る。すなわち, 肥満の dynamic state, あるいは static state に扔ける代謝率の相異によるためである。

dynamic state にあってはエネルギーの過剩摂取に伴 ら反応が主体となり, 脂肪酸の合成も促進されている が， turn over rate もまた六進している。ところが static state の脂肪動員機構はむしろ低下していること である。したがっていずれの場合もその代謝率をみきわ めて論議せねばならないとい党る。

肥満者にブドウ糖を負荷すると著明に脂肪酸の低下を みるものと，まったく反応のみないものがあることもこ のことを裏付けている。+30\% 以上を示すような異常 肥満体にあっては, 絶食, 運動によってもその反応性は そしく, 血中脂酸の上昇はみられない。すなわち, 脂酸 動員機構は常に低下していると考えられる。細胞内 LPL 活性の低下があることも証明され, 老化細胞と同じ態度 を示す。とくに脂酸動員性作用の強い成長ホルモンの分 泌機構が著明に低下していることも興味ある事実であ
る。

一方, 中性脂肪の利用に関与する血中 LPL 活性む糖 尿病患者と同様低下しており，とくに dextran sulfate 負荷後の LPL の上昇反応がみられないことも異常肥満 の特徴といえる。

以上諸種の所見は, 脂肪酸合成の促進, 脂酸動員機構 の低下, 中性脂肪利用の低下など一見矛盾したような反 応を一部に示すも, static state では結果的に脂肪の貯 積, 高脂血, やせにくいなどの現象を示すものと解釈さ れる。

\section{$4 \cdot 3$ その他の特性}

肥満度とは関係がないが, 肥満者にあっては常に副腎 皮質機能の元進がみられる。また腎血流量, 糸球体口過 量の減少, 血中の抗利尿ホルモンの高值が証明されてい る。

このようなことが，どのような機序で起こるかについ ては充分汇かってはいないが，肥満者の高血圧の合 併, 血糖上昇などの臨床症状もいくぶん理解できるよう な気がする。また，そのほかなんらかの代謝特性と結び ついているものと考えられる。

\section{5 肥満の発生機序}

以上, 各種の特性をひろいあげてみたが, その発生機 序としては, すなわち, 遺伝的背景であり, その上に先 天的な酵素欠損なども含まれるであろらが，食欲允進と いう摂取エネルギーの過大がまず第一の条件となり脂肪 の合成を高め, さらに血中インスリンの上昇などの合成 機構が協調し, 片方では脂肪酸動員機構の低下が働く。 一方肥满に特有な運動量の低下などが加わって, 一層肥 満は促進され, 終局的には固定化されるものであろら。

これらを臨床的には単純性肥満 (simple obestiy) と して各種の原因によって起こされた二次性肥満（secondary obesity) と区別して考えられている。単純性肥満 の原因を模式化したものが 図-7 である。

肥満とくに単純性肥満についての代謝特性について, 生理的化学過程を含めて概説したが，すべてを説明でき た訳ではない。とくに遺伝的素因についての研究は今後 の研究にまたねばならない。たとえば動物実験で遺伝性

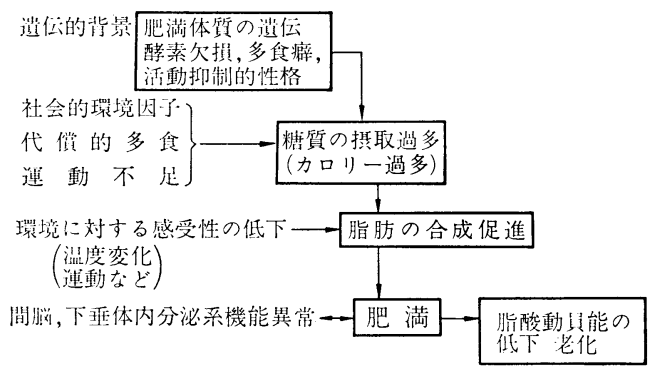

図-7 単純性肥満の原因 
肥満マウスの脂肪酸動員の低下は, 脂肪組織で注脂肪酸

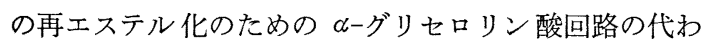
りに，一種の他のモノグリセリド回路が存在するためで はないかとする報告 ${ }^{10)}$ もるくらいで, まだ多数の未解 決の分野が残されていると考える。

いずれにしても, 肥満は人類とともに常に存在し, 文 明とともに発展したと考えられる。人命に多大の影響, とくに死因につながる合併症, たとえば血管硬化症, 循 環不全, 脳出血などの誘因, 脂肪肝, 糖尿病の多発など 社会医学的にも重大な問題を提起しつづけるであろう。

(昭和 45 年 6 月 26 日受理)

\section{文献}

1) J.A. Lennon, W.J. Brech, E.S. Gordon, Metabolism, 16, 503 (1967)
2) C.H. Wydham, C.G. Williams, H. Loots, J. appl. physiol, 24, 282 (1968)

3) D.J. Galton, Br. med. J., 2, 1498 (1966)

4) D.J. Galton, G.A. Bray, J. Clin. Enodocr. Metab., 27, 1573 (1917)

5) L.B. Salans, J.L. Knittle, J. Hirsch, J. Clin. Invest., 47, 153 (1968)

6) S. Westman, Biochem. J., 106, 543 (1968)

7) E.P Paulsen, L. Richenderfer, F. Ginsberg-Fellner, Diabetes, 17, 261 (1968)

8) S.S. Solomon, J.W. Ensick, R.H. Williams, Metabolism, 17, 528 (1968)

9）弓狩 “日本代謝学会記録” IV, p. 59 (1967)

10) J. Stein, J. Anderson, G. Hollifield, Metabolism, 16, 658 (1967)

11) P.J. Randle, P.B. Garland, C.N. Hales, E.A. Newsholme, Ciba Found. Colloq. Endocr., 15, 192 (1964)

界面活性剂等生産・出荷実績前年比

単価 : t

\begin{tabular}{|c|c|c|c|c|c|c|c|c|c|}
\hline & & & & 生 & 産 & & 出 & 荷 & \\
\hline & 品 & & 目 & 44 年 (A) & 43 年 (B) & $\frac{\mathrm{A}}{\mathrm{B}} \%$ & 44 年 (A) & 43 年 (B) & $\frac{\mathrm{A}}{\mathrm{B}} \%$ \\
\hline & & 口 & - & 2,798 & 2,485 & 113 & 2,928 & 2,517 & 116 \\
\hline & 陰 & 乳 & & 13,984 & 12,654 & 111 & 13,816 & 12,599 & 110 \\
\hline & & ^ & r & 3,022 & 3,212 & 94 & 2,966 & 3,200 & 93 \\
\hline 界 & 1 & そ & 油 & 2,562 & 2,356 & 109 & 2,536 & 2,294 & 111 \\
\hline & & 跘 & 鉱 油 系 & 42,806 & 27,528 & 155 & 42,443 & 27,743 & 153 \\
\hline 面 & オ & 桶 & 高級アルコール系 & 16,426 & 14,674 & 112 & 16,363 & 14,497 & 113 \\
\hline & 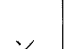 & 洗 & 計 & 59,232 & 42,202 & 140 & 58,806 & 42,240 & 139 \\
\hline 活 & & 高系 & アルコール乳化油 & 12,218 & 12,281 & 99 & 12,249 & 12,190 & 100 \\
\hline & & そ & 他 & 34,010 & 31,519 & 108 & 33,193 & 31,565 & 105 \\
\hline 性 & 陽 & & v & 18,023 & 15,773 & 114 & 16,657 & 14,051 & 119 \\
\hline & 非 & ポリ & チレングリコール系 & 69,342 & 60,130 & 115 & 61,905 & 55,512 & 112 \\
\hline 唷 & 辈 & 多 & 五アルコール系 & 7,115 & 6,743 & 106 & 6,274 & 5,943 & 106 \\
\hline & 齐 & そ & 他 & 25,335 & 20,826 & 122 & 23,195 & 19,899 & 117 \\
\hline & & & 計 & 101,792 & 87,699 & 116 & 91,374 & 81,354 & 112 \\
\hline & 両 & ja & 1 オ & 1,959 & 1,591 & 123 & 1,903 & 1,493 & 127 \\
\hline & の他 & 助斉 & （フイックス剂等） & 7,548 & 6,122 & 123 & 7,343 & 6,169 & 119 \\
\hline & 合 & & 計 & 257,148 & 217,894 & 118 & 243,771 & 209,672 & 116 \\
\hline 蒸 & 留 & T & $ル=-ル$ & 7,402 & 7,132 & 104 & 5,959 & 5,322 & 112 \\
\hline 還 & 元 & 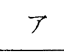 & $ル=-ル$ & 16,165 & 18,872 & 86 & 11,784 & 12,718 & 93 \\
\hline & 合 & & 計 & 23,567 & 26,004 & 91 & 17,743 & 18,040 & 98 \\
\hline
\end{tabular}

